\title{
KARAKTERISTIK BUBUR BAYI INSTAN BERBAHAN DASAR TEPUNG GARUT DAN TEPUNG KACANG MERAH
}

\author{
Restiara Tamrin ${ }^{1)}$, Shanti Pujilestari ${ }^{1)}$ \\ 1) Program Studi Teknologi Pangan Fakultas Teknologi Industri Pertanian \\ Universitas Sahid Jakarta, Indonesia \\ hajjahshanti@yahoo.co.id
}

\begin{abstract}
Infants require instant baby food to meet their nutritional needs. The use arrowroot flour is needed to replace the use of carbohydrates from rice and red beans as a protein source. The purpose of this study was to determine the characteristics of instant baby porridge with arrowroot powder formulation and the best red bean flour. The results showed that the characteristics of the baby porridge instant influenced by the formulation of arrowroot powder and red bean flour different (70: 30\%, 60:40\%, 50:50\%, 40:60\%, 30: 70\% (w/w) ), of the moisture, ash, protein, fat, carbohydrates, viscosity, water absorption and density Kamba, organoleptic tests on the viscosity of instant baby food is thawed, and the color, aroma and texture of instant baby porridge that is not disbursed. Arrowroot powder formulations are $70 \%(w / w)$ and $30 \%(w / w)$ red bean flour, with the characteristics of the water content $(6.47 \%(w / w))$, ash $(3.71 \%(w / w))$, protein $(16.38 \%(w / w))$, fat $(6.62 \%(w /$ $w)$ ), carbohydrate $(66.82 \%(w / w))$, dietary fiber $(9.64 \%(b / b))$, and calcium (360.49 $\mathrm{mg} /$ $100 \mathrm{~g}(\mathrm{w} / \mathrm{w}))$, viscosity (cp 556.67), water absorption (161.49\% ( $/ \mathrm{w})$ ), Kamba density (0, $56 \mathrm{~g} / \mathrm{ml}(\mathrm{w} / \mathrm{v})$ ), and rehydration time (39.8 s). Characteristics of instant baby porridge in accordance with SNI 01-7111.1-2005 in fat, protein and calcium, and even the density of Kamba and rehydration better time than commercial instant baby porridge
\end{abstract}

Key words: instant baby porridge, characteristics, arrowroot flour, red bean flour

ABSTRAK. Bayi memerlukan bubur bayi instan untuk memenuhi kebutuhan gizinya. Penggunaan tepung garut diperlukan untuk menggantikan karbohidrat dari beras dan penggunaan kacang merah sebagai sumber protein. Tujuan dari penelitian ini adalah untuk mengetahui karakteristik bubur bayi instan dengan formulasi tepung garut dan tepung kacang merah yang terbaik. Hasil penelitian ini menunjukkan bahwa karakteristik bubur bayi instan dipengaruhi oleh formulasi tepung garut dan tepung kacang merah yang berbeda (70:30\%, 60:40\%, 50:50\%, 40:60\%, 30:70\% (b/b)), yaitu pada kadar air, abu, protein, lemak, karbohidrat, kekentalan, daya serap air dan densitas kamba, uji organoleptik pada viskositas bubur bayi instan yang dicairkan, dan pada warna, aroma dan tekstur bubur bayi instan yang tidak dicairkan. Formulasi terbaik adalah tepung garut 70\% (b/b) dan 30\% (b/b) tepung kacang merah, dengan karakteristik kadar air $(6,47 \%(b / b))$, abu $(3,71 \%(b / b))$, protein $(16,38 \%(b / b))$, lemak $(6,62 \%(b / b))$, karbohidrat $(66,82 \%(b / b))$, serat pangan $(9,64 \%(b / b))$, and calcium (360,49 mg/100 g (b/b)), viscosity (556,67 cp), water absorption (161,49\% (v/b)), densitas kamba $(0,56 \mathrm{~g} / \mathrm{ml}(\mathrm{b} / \mathrm{v}))$, dan waktu rehidrasi $(39,8 \mathrm{~s})$. Karakteristik bubur bayi instan sesuai dengan SNI 01-7111.1-2005 pada lemak, protein dan kalsium, bahkan densitas kamba dan waktu rehidrasi lebih baik dari bubur bayi instan komersil.

Kata-kata kunci : bubur bayi instan, karakteristik, tepung garut, tepung kacang merah 


\section{PENDAHULUAN}

Bubur bayi instan merupakan bubur yang memiliki komponen penyusun bubur bayi yang bersifat instan sehingga dalam penyajiannya tidak diperlukan proses pemasakan. Kebutuhan bayi akan zat gizi makin meningkat seiring dengan bertambahnya umur bayi sedangkan ASI kurang dapat mencukupi kebutuhan zat gizi bayi, sehingga bayi membutuhkan makanan pendamping ASI (MP-ASI). Umumnya bubur bayi instan yang beredar di Indonesia dibuat dengan bahan utama beras putih dan beras merah yang dikenal sebagai bahan pokok utama. Padahal, jenis bahan pangan lainnya seperti pati dan tepung dari umbi-umbian tidak kalah kandungan gizinya dibandingkan beras (Krisnatuti dan Yenrina, 2000).

Umbi garut (Marantha arundinaceae L.) merupakan salah satu bahan pangan lokal dan berpotensi sebagai sumber pangan alternatif, khususnya sebagai pengganti sumber karbohidrat. Analisis komposisi gizi terhadap tepung garut menunjukkan bahwa dalam 100 gram tepung garut mengandung kalori sebesar 355 kalori, karbohidrat 85,2 gram, lemak 0,2 gram, dan protein 0,7 gram (Koswara, 2013). Kadar protein tepung garut yang relatif rendah dapat disiasati dengan mengombinasikannya bersama bahan pangan sumber protein nabati, salah satunya adalah kacang-kacangan. Jenis kacang yang dipilih untuk pembuatan bubur bayi instan ini adalah kacang merah. Kacang merah (Phaseolus vulgaris L.) memiliki kandungan protein cukup tinggi, yaitu antara 21-27\% (Rukmana, 2009). Selain itu, kacang merah juga mengandung vitamin B, folasin, tiamin, kalsium, fosfor, dan mengandung lebih banyak asam lemak omega-3 khususnya ALA yang penting bagi pertumbuhan dan fungsi otak (Kartikasari, 2006).
Umbi garut merupakan sumber daya lokal yang dapat tumbuh baik pada iklim tropis Indonesia sehingga memiliki tingkat produktivitas tinggi, namun sampai saat ini, tanaman garut di Indonesia belum dibudidayakan secara intensif. Data produktivitas umbi garut di Indonesia tahun 2013 di dua provinsi utama penghasil garut terbesar yaitu Jawa Barat (Garut dan Kuningan) dan Jawa Tengah (Semarang) adalah sebesar 150 ton (Direktorat Jenderal Tanaman Pangan Kementrian Pertanian, 2013). Sedangkan, untuk kacang merah di Indonesia telah dibudidayakan dengan baik dan memiliki tingkat produktivitas tinggi dan terus mengalami peningkatan setiap tahunnya, tercatat pada tahun 2011 hingga 2013 produksi kacang merah di Indonesia secara berturut-turut adalah sebesar 92.508 ton, 93.416 ton, dan 103.376 ton (BPS, 2013). Dengan demikian program diversifikasi pangan melalui sumber daya lokal diharapkan dapat meningkatkan ketahanan pangan Indonesia. Pada penelitian ini, dilakukan formulasi bubur bayi instan sebagai MP-ASI dengan menggunakan tepung garut dan tepung kacang merah, diharapkan memiliki sifat organoleptik, kimia dan fisik yang baik dan mampu mencukupi kebutuhan gizi bayi usia 6-12 bulan.

\section{METODOLOGI PENELITIAN}

\section{Bahan dan Alat}

Bahan utama yang digunakan dalam pembuatan bubur bayi instan adalah tepung garut dan tepung kacang merah yang diperoleh di pasar swalayan di Jakarta Barat. Bahan lain yang digunakan adalah susu bubuk skim, gula halus, minyak nabati, dan air. Bahan untuk analisis meliputi $\mathrm{H}_{2} \mathrm{SO}_{4}, \mathrm{HgO}, \mathrm{K}_{2} \mathrm{SO}_{4}$, $\mathrm{NaOH}, \mathrm{Na}_{2} \mathrm{~S}_{2} \mathrm{O}_{3}, \mathrm{H}_{3} \mathrm{BO}_{3}, \mathrm{HCl}$, heksan, petroleum eter, natrium fosfat, enzim termamyl, $\mathrm{HNO}_{3}$ dan $\mathrm{HClO}_{4}$.

Alat-alat yang digunakan dalam pembuatan bubur bayi instan tepung garut dan tepung kacang merah adalah oven, alat ukur (timbangan dan gelas ukur) dan alat penunjang (wadah, blender, aluminium foil, saringan/ayakan 80 mesh, loyang, kompor dan panci). Alat-alat yang 
digunakan untuk analisis kimia terdiri dari cawan porselen, oven, desikator, timbangan analitik, tabung kjedahl, erlenmeyer, labu ukur, gelas ukur, pipet, kertas saring, labu lemak, tanur, ekstraksi soxhlet, hot plate, dan tabung reaksi. Alat untuk uji fisik adalah viskosimeter.

\section{Metode Penelitian}

Metode penelitian yang digunakan dalam penelitian ini adalah Rancangan Acak Langkap (RAL) satu faktor dengan lima taraf dan tiga kali ulangan. Perlakuan penelitian adalah tepung garut dan tepung kacang merah \% (b/b) yang bervariasi yaitu 70:30, 60:40, 50:50, 40:60, dan $30: 70$. Penelitian ini dilaksanakan di Laboratorium Teknologi Pangan Universitas Sahid Jakarta, Laboratorium Institut Pertanian Bogor, dan Laboratorium Balai Besar Penelitian dan Pengembangan Pascapanen Pertanian.

\section{Pembuatan Bubur Bayi Instan}

Pembuatan bubur bayi instan dilakukan dengan mencampur semua bahan sedikit demi sedikit sesuai dengan formulasi. Campuran bahan ditambahkan air, lalu dimasak selama 10 menit dengan suhu $75^{\circ} \mathrm{C}$ hingga campuran bahan mengental. Bubur yang telah matang kemudian didinginkan dan dioleskan di atas loyang yang sudah dilapisi aluminuim foil, kemudian bubur dikeringkan di dalam oven selama 3 jam dengan suhu $125^{\circ} \mathrm{C}$. Setelah kering, bubur dihaluskan dengan blender, bubur yang sudah halus tersebut lalu dikeringkan lagi didalam oven selama 15 menit dengan suhu $100^{\circ} \mathrm{C}$. Bubur yang sudah kering selanjutnya dihaluskan lagi dengan blender dan diayak dengan ayakan 80 mesh. Formulasi bubur bayi instan tepung garut dan tepung kacang merah dapat dilihat pada Tabel 1.

Tabel 1. Formulasi bubur bayi instan tepung garut dan tepung kacang merah

\begin{tabular}{lc}
\hline \multicolumn{1}{c}{ Jenis Bahan } & Persentasi (w/w) \\
\hline Tepung garut dan tepung kacang merah & $10,45 \%$ \\
\hline Susu bubuk skim & $8,62 \%$ \\
\hline Gula halus & $0,86 \%$ \\
\hline Minyak nabati & $1,72 \%$ \\
\hline Air & $78,35 \%$ \\
\hline
\end{tabular}

Variabel mutu/karakteristik yang diamati pada bubur bayi instan yang dibuat pada penelitian ini meliputi mutu kimia yaitu kadar air, abu, protein, lemak, karbohidrat; mutu fisik yaitu viskositas, daya serap air, dan densitas kamba; mutu organoleptik adalah mutu hedonik terhadap warna, aroma, rasa, tekstur, kekentalan, dan uji rangking pada bubur bayi instan sudah diseduh, serta warna, aroma, tekstur pada bubur bayi instan tidak diseduh. Mutu penunjang adalah waktu rehidrasi, kadar serat pangan dan kalsium. Sebagai pembanding mutu, SNI nomor 01-711.12005 Syarat Mutu MP-ASI bubuk instan (Badan Standarisasi Nasional, 2005) dan bubur bayi komersil.

\section{HASIL DAN PEMBAHASAN}

\section{Mutu Kimia Bubur Bayi Instan}

Nilai rata-rata mutu kimia pada bubur bayi instan dengan formulasi tepung garut dan tepung kacang merah dapat dilihat pada Tabel 2.

Tabel 2. Nilai rata-rata mutu kimia bubur bayi instan dengan formulasi tepung garut dan tepung kacang merah

\begin{tabular}{lccccc}
\hline \multirow{2}{*}{$\begin{array}{c}\text { Parameter } \\
(\%(\mathrm{~b} / \mathrm{b}))\end{array}$} & $70: 30$ & $60: 40$ & $50: 50$ & $40: 60$ & $30: 70$ \\
\cline { 2 - 5 } & $6,47 \pm 0,24^{\mathrm{b}}$ & $6,83 \pm 0,05^{\mathrm{c}}$ & $7,14 \pm 0,13^{\mathrm{d}}$ & $5,58 \pm 0,25^{\mathrm{a}}$ & $6,24 \pm 0,01^{\mathrm{b}}$ \\
\hline Kadar air & $3,71 \pm 0,18^{\mathrm{a}}$ & $4,06 \pm 0,03^{\mathrm{b}}$ & $4,16 \pm 0,02^{\mathrm{b}}$ & $4,39 \pm 0,01^{\mathrm{c}}$ & $4,49 \pm 0,02^{\mathrm{c}}$ \\
\hline Kadar abu & $16,38 \pm 0,41^{\mathrm{a}}$ & $18,08 \pm 0,54^{\mathrm{bc}}$ & $17,53 \pm 0,18^{\mathrm{b}}$ & $18,26 \pm 0,29^{\mathrm{cd}}$ & $18,87 \pm 0,10^{\mathrm{d}}$ \\
\hline Kadar protein & $6,62 \pm 0,19^{\mathrm{a}}$ & $6,64 \pm 0,21^{\mathrm{a}}$ & $6,36 \pm 0,29^{\mathrm{a}}$ & $6,58 \pm 0,14^{\mathrm{a}}$ & $7,38 \pm 0,19^{\mathrm{b}}$ \\
\hline Kadar lemak & $66,82 \pm 0,25^{\mathrm{d}}$ & $64,40 \pm 0,53^{\mathrm{b}}$ & $64,80 \pm 0,37^{\mathrm{bc}}$ & $65,19 \pm 0,38^{\mathrm{c}}$ & $63,02 \pm 0,29^{\mathrm{a}}$ \\
\hline Kadar karbohidrat & & & & & \\
\hline
\end{tabular}


Keterangan: Angka yang diikuti dengan huruf superscript berbeda (a,b,c,d) menunjukkan beda nyata $(\alpha=0,05)$

\section{Kadar air}

Kadar air bubur bayi instan meningkat dengan bertambahnya konsentrasi tepung kacang merah, hal ini diduga disebabkan oleh kandungan protein yang terdapat pada tepung kacang merah. Menurut Chilmijati (1999), tepung yang memiliki kandungan protein yang lebih tinggi bersifat menyerap air lebih kuat dibandingkan tepung dengan kandungan protein yang rendah. Kandungan protein tepung kacang merah lebih tinggi $(22,85 \%)$ dibandingkan kandungan protein tepung garut $(0,35 \%)$, sehingga dapat dikatakan kemampuan menyerap air tepung kacang merah lebih tinggi sehingga kadar air bubur bayi instan pun juga tinggi. Kadar air bubur bayi instan dengan formulasi tepung garut dan tepung kacang merah yang dihasilkan berkisar antara 5,58 - 7,14\%. Spesifikasi MP-ASI bubuk instan oleh SNI 01-7111.1-2005, menetapkan kadar air dalam $100 \mathrm{~g} \mathrm{MP}$ ASI adalah tidak lebih dari $4 \mathrm{~g}$. Semua formula bubur bayi instan dengan formulasi tepung garut dan tepung kacang merah memiliki kadar air yang lebih tinggi dibanding SNI. Akibat hal tersebut maka diduga daya simpan bubur bayi instan tidak lebih lama dari bubur bayi yang memenuhi standar air SNI, disebabkan tingginya kadar air akan menyediakan media untuk tumbuhnya mikroorganisme.

\section{Kadar abu}

Berdasarkan hasil analisis kadar abu terhadap bubur bayi instan menunjukkan bahwa semakin tinggi konsentrasi tepung kacang merah dalam bubur bayi instan, semakin tinggi pula kadar abu yang terkandungnya. Hal ini diduga disebabkan oleh kandungan mineral dalam kacang merah yang cukup tinggi yaitu sekitar $3,7 \%$ dalam $100 \mathrm{~g}$ bahan (Cahyani, 2011), sedangkan garut hanya berkisar $1.3-1,4 \%$ (Koswara, 2013). Kadar abu bubur bayi instan formulasi tepung garut dan tepung kacang merah berkisar dari 3,71 - 4,49\%, nilai rata-rata kadar abu bubur bayi instan tersebut terlalu tinggi dari standar MP-ASI bubuk instan yang ditetapkan oleh SNI 01 7111.1-2005, dimana syarat kadar abu pada MP-ASI tidak boleh melebihi $3,5 \mathrm{~g}$ per $100 \mathrm{~g}$. Walau asupan mineral tinggi misalnya calcium, iodium, kalium menimbulkan efek buruk pada kesehatan, pemberian bubur bayi instan hanya berlangsung pada usia $6-12$ bulan sehingga diduga tidak terjadi efek kesehatan yang buruk tersebut.

\section{Kadar protein}

Kadar protein bubur bayi instan meningkat seiring dengan bertambahnya konsentrasi tepung kacang merah. Tepung kacang merah memang sengaja ditambahkan sebagai formulasi mendampingi tepung garut karena kandungan proteinnya yang tinggi yaitu sebesar $22,85 \%$ sehingga dapat melengkapi kekurangan protein pada tepung garut. Kadar protein bubur bayi instan berkisar dari $16,38 \%$ pada formulasi $70: 30$ hingga 18,87\% pada formulasi 30:70. Kadar protein yang diperoleh tersebut sesuai dengan standar protein MP-ASI bubuk instan yang ditetapkan dalam SNI 01-7111.1-2005, dimana kandungan protein disyaratkan berkisar antara $8-22 \mathrm{~g}$ per $100 \mathrm{~g}$.

\section{Kadar lemak}

Kadar lemak bubur bayi instan meningkat dengan bertambahnya konsentasi tepung kacang merah, hal ini diduga disebabkan kandungan lemak tepung kacang merah $(0,48 \mathrm{~g})$ lebih tinggi dari kandungan lemak tepung garut $(0,31 \mathrm{~g})$. Spesifikasi SNI 01 7111.1-2005 tentang MP-ASI bubuk instan mensyaratkan kandungan lemak sebesar 6 - $15 \mathrm{~g}$ dalam $100 \mathrm{~g}$ MP-ASI. Sementara itu kadar lemak bubur bayi instan dengan formulasi tepung garut dan tepung kacang merah berkisar antara 6,62 - 7,38\%, hal ini berarti bahwa kelima formulasi bubur bayi instan yang dihasilkan mengandung lemak dalam rentang yang disyaratkan SNI.

\section{Kadar karbohidrat}

Kadar karbohidrat menurun dengan bertambahnya konsentrasi tepung kacang merah. Hal ini diduga disebabkan kandungan karbohidrat tepung kacang merah $(12,83$ g) lebih rendah 
dibandingkan kandungan karbohidrat tepung garut $(16,56 \mathrm{~g})$. Bubur bayi instan memiliki kadar karbohidrat berkisar dari $63,02 \%$ hingga $66,82 \%$. Spesifikasi SNI 01-7111.1-2005 tentang MP-ASI bubuk instan mensyaratkan kandungan karbohidrat < $30 \mathrm{~g}$ dalam $100 \mathrm{~g}$ MP-ASI. Bila karbohidrat bubur bayi instan lebih tinggi maka diduga akan menimbulkan kegemukan/tumpukan lemak.

\section{Mutu Fisik Bubur Bayi Instan}

Nilai rata-rata mutu fisik pada bubur bayi instan dengan formulasi tepung garut dan tepung kacang merah dapat dilihat pada Tabel 3.

Tabel 3. Nilai rata-rata mutu fisik bubur bayi instan dengan formulasi tepung garut dan tepung kacang merah

\begin{tabular}{|c|c|c|c|c|c|}
\hline \multirow{2}{*}{ Parameter } & \multicolumn{5}{|c|}{ Formulasi Tepung Garut : Tepung Kacang Merah } \\
\hline & $70: 30$ & $60: 40$ & $50: 50$ & $40: 60$ & $30: 70$ \\
\hline Viskositas (cp) & $556,67 \pm 0,00^{d}$ & $414,33 \pm 0,01^{\mathrm{c}}$ & $235,33 \pm 0,01^{b}$ & $171,67 \pm 0,00^{\mathrm{a}}$ & $145,00 \pm 0,00^{a}$ \\
\hline Daya serap air (\%) & $161,49 \pm 8,73^{a}$ & $164,15 \pm 4,73^{a}$ & $171,95 \pm 4,98^{\mathrm{ab}}$ & $179,12 \pm 9,70^{b}$ & $182,97 \pm 5,47^{b}$ \\
\hline Densitas kamba (g/ml) & $0,56 \pm 15,28^{\mathrm{a}}$ & $0,59 \pm 39,00^{b}$ & $0,55 \pm 31,01^{\mathrm{a}}$ & $0,54 \pm 5,77^{\mathrm{a}}$ & $0,54 \pm 5,00^{\mathrm{a}}$ \\
\hline
\end{tabular}

\section{Viskositas}

Viskositas bubur bayi instan menurun dengan bertambahnya konsentrasi tepung kacang merah, hal ini diduga karena rendahnya kandungan karbohidrat pada kacang merah dibandingkan tepung garut. Menurut Mulya (1994), kekentalan bubur instan dipengaruhi oleh jumlah karbohidrat yang tergelatinisasi. Nilai viskositas bubur bayi instan berkisar dari 145,00 - 556,67 cp. Bubur dengan viskositas 1000-3000 cp sangat cocok untuk makanan penganti ASI, karena memiliki sifat tidak terlalu kental dengan konsistensi menyerupai sup (Mulya, 1994). Viskositas kelima formulasi bubur bayi instan tepung garut dan tepung kacang merah lebih rendah dari ketentuan tersebut, dimana dengan penambahan air 1:3 karakteristiknya lebih encer dari yang dipersyaratkan.

\section{Daya serap air}

Daya serap air semakin meningkat dengan bertambahnya konsentrasi tepung kacang merah, hal ini diduga karena kandungan protein yang lebih tinggi pada tepung kacang merah dibandingkan tepung garut. Menurut Mirdhayati (2004), daya serap air suatu bahan dipengaruhi oleh komponen-komponen penyusunnya seperti protein, dimana protein bersifat menyerap air.

\section{Densitas kamba}

Nilai densitas kamba semakin meningkat dengan bertambahnya konsentrasi tepung kacang merah, hal ini diduga karena kadar air tepung kacang merah yang lebih tinggi dibandingkan tepung garut. Menurut Wiranatakusumah dkk (1992), parameter yang mempengaruhi densitas kamba salah satunya adalah kadar air. Kadar air bubur bayi instan meningkat dengan bertambahnya konsentrasi tepung kacang merah yaitu berkisar antara 5,58 - 7,14\%. Semakin tinggi kadar air, densitas kamba pun juga tinggi, sebab air dalam bahan dapat mengganggu dan menguraikan struktur protein sehingga butiran bahan menjadi porous (Wiranatakusumah, 1992). Nilai densitas kamba $(\mathrm{g} / \mathrm{ml})$ menentukan kepadatan partikel yang menempati ruang pada volume tertentu, densitas kamba yang tinggi menunjukkan bahwa produk tersebut lebih ringkas (non voluminous) sehingga memudahkan dalam pengemasan, penyimpanan dan pengangkutan (Widowati dkk, 2010). Nilai densitas kamba bubur bayi instan dengan formulasi tepung garut dan tepung kacang merah berkisar antara 0,543-0,588 $\mathrm{g} / \mathrm{ml}$. Nilai tersebut melebihi rentang densitas kamba bubur komersial, yaitu 0,37-0,50 $\mathrm{g} / \mathrm{ml}$ (Elvizahro, 2011). Hal tersebut berarti bahwa bubur bayi instan dengan fomulasi tepung garut dan tepung kacang merah diduga lebih baik dalam hal pengemasan, 
penyimpanan, dan pengangkutan dibandingkan bubur bayi instan komersial karena memiliki densitas kamba yang lebih tinggi.

\section{Mutu Organoleptik Bubur Bayi Instan}

Penilaian mutu organoleptik bubur bayi instan dilakukan melalui uji mutu hedonik dan uji rangking oleh 25 orang panelis semi terlatih. Nilai rata-rata mutu organoleptik pada bubur bayi instan dengan formulasi tepung garut dan tepung kacang merah yang sudah diseduh dapat dilihat pada Tabel 4, sedangkan nilai ratarata mutu organoleptik pada bubur bayi instan yang belum diseduh dapat dilihat pada Tabel 5.

Tabel 4. Nilai rata-rata mutu organoleptik bubur bayi instan dengan formulasi tepung garut dan tepung kacang merah yang sudah diseduh

\begin{tabular}{lccccc}
\hline \multirow{2}{*}{ Parameter } & \multicolumn{5}{c}{ Formulasi Tepung Garut : Tepung Kacang Merah } \\
\cline { 2 - 5 } & $70: 30$ & $60: 40$ & $50: 50$ & $40: 60$ & $30: 70$ \\
\hline Warna & $4,1 \pm 0,10$ & $4,28 \pm 0,04$ & $4,31 \pm 0,10$ & $3,87 \pm 0,20$ & $3,85 \pm 0,38$ \\
\hline Aroma & $3,9 \pm 0,27$ & $3,81 \pm 0,02$ & $3,64 \pm 0,20$ & $3,72 \pm 0,17$ & $3,69 \pm 0,06$ \\
\hline Rasa & $3,1 \pm 0,26$ & $2,95 \pm 0,12$ & $3,17 \pm 0,16$ & $3,05 \pm 0,08$ & $2,99 \pm 0,20$ \\
\hline Tekstur & $3,7 \pm 0,28$ & $3,28 \pm 0,21$ & $3,48 \pm 0,11$ & $3,35 \pm 0,16$ & $3,33 \pm 0,19$ \\
\hline Kekentalan & $3,1 \pm 0,48^{\mathrm{c}}$ & $2,79 \pm 0,29^{\mathrm{bc}}$ & $2,21 \pm 0,26^{\mathrm{a}}$ & $2,56 \pm 0,11^{\mathrm{abc}}$ & $2,35 \pm 0,19^{\mathrm{ab}}$ \\
\hline Uji rangking & $0,30 \pm 0,30^{\mathrm{b}}$ & $0,02 \pm 0,10^{\mathrm{ab}}$ & $0,05 \pm 0,07^{\mathrm{ab}}$ & $-0,18 \pm 0,06^{\mathrm{a}}$ & $-0,18 \pm 0,20^{\mathrm{a}}$ \\
\hline
\end{tabular}

Keterangan: Angka yang diikuti dengan huruf superscript berbeda (a,b,c,d) menunjukkan beda nyata $(\alpha=0,05)$

Warna $\quad: 1=$ Kuning tua, $2=$ Kuning muda, $3=$ Kuning kecoklatan, $4=$ Coklat muda, 5 $=$ Coklat kemerahan

Aroma $\quad: 1=$ Sangat langu, 2 = langu, $3=$ agak langu, $4=$ tidak langu, $5=$ sangat tidak langu

Rasa $\quad: 1=$ Sangat tidak manis, $2=$ Tidak manis, $3=$ Agak manis, $4=$ Manis, $5=$ Sangat manis

Tekstur $\quad: 1=$ Sangat tidak lembut, $2=$ Tidak lembut, $3=$ Agak lembut, $4=$ Lembut, $5=$ Sangat lembut

Kekentalan $: 1=$ Sangat kental, $2=$ Kental, $3=$ Agak kental, $4=$ Tidak kental, $5=$ Sangat tidak kental

Tabel 5. Nilai rata-rata mutu organoleptik bubur bayi instan dengan formulasi tepung garut dan tepung kacang merah yang tidak diseduh

\begin{tabular}{lccccc}
\hline \multirow{2}{*}{ Parameter } & \multicolumn{5}{c}{ Formulasi Tepung Garut : Tepung Kacang Merah } \\
\cline { 2 - 6 } & $70: 30$ & $60: 40$ & $50: 50$ & $40: 60$ & $30: 70$ \\
\hline Warna & $2,3 \pm 0,18^{\mathrm{a}}$ & $2,8 \pm 0,26^{\mathrm{b}}$ & $3,3 \pm 0,24^{\mathrm{c}}$ & $4,1 \pm 0,08^{\mathrm{d}}$ & $4,8 \pm 0,09^{\mathrm{e}}$ \\
\hline Aroma & $3,9 \pm 0,15^{\mathrm{c}}$ & $3,5 \pm 0,12^{\mathrm{b}}$ & $3,2 \pm 0,11^{\mathrm{ab}}$ & $3,1 \pm 0,16^{\mathrm{a}}$ & $3,0 \pm 0,28^{\mathrm{a}}$ \\
\hline Tekstur & $4,0 \pm 0,06^{\mathrm{c}}$ & $3,4 \pm 0,13^{\mathrm{b}}$ & $3,2 \pm 0,12^{\mathrm{b}}$ & $2,6 \pm 0,07^{\mathrm{a}}$ & $2,5 \pm 0,08^{\mathrm{a}}$ \\
\hline Ken
\end{tabular}

Keterangan: Angka yang diikuti dengan huruf superscript berbeda (a,b,c,d) menunjukkan beda nyata $(\alpha=0,05)$

Warna $\quad: 1=$ Kuning tua, $2=$ Kuning muda, $3=$ Kuning kecoklatan, $4=$ Cokelat muda, $5=$ Cokelat kemerahan

Aroma $\quad: 1=$ Sangat langu, 2 = langu, $3=$ agak langu, $4=$ tidak langu, $5=$ sangat tidak langu

Tekstur $\quad: 1=$ Sangat tidak lembut, $2=$ Tidak lembut, $3=$ Agak lembut, $4=$ Lembut, $5=$ Sangat lembut 


\section{Warna}

Warna bubur bayi instan seduh memperlihatkan hasil bahwa menurut panelis warna kelima formulasi yang yang ujikan memiliki warna yang sama yaitu cokelat muda. Penilaian panelis berbanding terbalik apabila bubur bayi tidak diseduh. Pada bubur bayi yang tidak diseduh, perbedaan warna antar tiap formulasi dapat dengan jelas dibedakan. Kisaran nilai rata-rata warna bubur bayi instan formulasi 70:30 hingga 30:70 berturut-turut adalah kuning muda, kuning kecoklatan, kuning kecoklatan, coklat muda, coklat kemerahan. Warna coklat dari bubur bayi instan diduga dipengaruhi oleh bahan baku dimana semakin banyak tepung kacang merah dalam formulasi, maka semakin coklat atau coklat kemerahan warna bubuk bubur bayi instan. Senyawa dalam kacang merah yang menyebabkan warna kemerahan tersebut adalah antosianin (Rukmana, 2009). Selain bahan baku, proses pengolahan juga diduga mempengaruhi warna bubur bayi instan (Fernando, 2008). Pada saat pengeringan, kandungan gula di dalam bubur bayi instan akan mengalami karamelisasi, selain itu juga terjadi reaksi maillard antar gula pereduksi dengan asam amino, sehingga menghasilkan warna yang lebih coklat.

\section{Aroma}

Penilaian panelis terhadap aroma bubur bayi instan seduh pada kelima formulasi menunjukkan aroma yang sama, yaitu tidak langu. Penilaian panelis terhadap aroma bubur bayi instan tidak diseduh berbeda dengan bubur bayi instan siap makan (sudah diseduh). Pada bubur bayi instan tidak diseduh penilaian panelis terhadap formulasi bubur bayi instan adalah mulai dari tidak langu hingga agak langu. Semakin tinggi konsentrasi kacang merah yang ditambahkan dalam formulasi, semakin agak langu aroma bubur bayi instan yang dihasilkan. Bau langu pada kacang merah disebabkan oleh enzim lipoksigenase (Kartikasari, 2006).

\section{Rasa}

Berdasarkan hasil uji hedonik kelima taraf perlakuan bubur bayi instan seduh memiliki rasa yang serupa yaitu agak manis. Rasa manis diduga berasal dari pemakaian gula halus yang ditambahkan.

\section{Tekstur}

Formulasi tepung garut dan tepung kacang merah tidak berpengaruh terhadap tekstur bubur bayi instan yang diseduh. Kelima formulasi bubur bayi instan yang sudah diseduh ternyata memiliki tekstur yang sama apabila mengalami penyeduhan yaitu agak lembut. Hasil penilaian panelis terhadap tekstur bubur bayi instan bubuk (tidak diseduh) menunjukkan hasil yang bervariasi mulai dari lembut, agak lembut, hingga tidak lembut. Tekstur dari suatu produk diduga dipengaruhi oleh bahan baku yang digunakan. Selain itu, proses pengayakan bubur bayi instan yang kurang halus diduga dapat menyebabkan tekstur berpasir pada bubur bayi instan (Elvizahro, 2011).

\section{Kekentalan}

Kekentalan bubur bayi instan yang sudah diseduh bervariasi mulai dari agak kental hingga kental. Semakin besar konsentrasi tepung kacang merah yang ditambahkan, tingkat kekentalan bubur bayi instan pun semakin tinggi. Kekentalan pada bubur bayi instan diduga dipengaruhi oleh kandungan pati bahan penyusun. Pati kacang merah memiliki sifat gelatinisasi yang sangat kental, sehingga menghasilkan kekentalan produk yang tinggi (Pontoh et al, 2004).

\section{Uji rangking}

Urutan tingkat kesukaan ini dipilih panelis berdasarkan tingkat kesukaan secara umum terhadap warna, aroma, rasa, tekstur dan kekentalan. Nilai urutan tingkat kesukaan secara umum tertinggi ditunjukkan oleh bubur bayi instan dengan formulasi 70:30 yaitu sebesar 0,30 (urutan pertama) sedangkan yang terendah ditunjukkan oleh bubur bayi instan dengan formulasi 30:70 yaitu $-0,18$ (urutan kelima). Bubur bayi instan formulasi 70:30 dengan tingkat kesukaan tertinggi memiliki karakteristik: warna skor 4,07 (coklat muda), aroma skor 3,95 ( tidak langu), rasa skor 3,11 (agak manis), tekstur skor 3,69 (lembut), dan kekentalan skor 3,09 (agak kental). 


\section{Data Penunjang}

Data penunjang dilakukan pada bubur bayi instan dengan formulasi tepung garut dan tepung kacang merah yang memiliki nilai rangking tertinggi dan viskositas terbaik, yaitu formulasi 70:30. Uji penunjang yang dilakukan meliputi waktu rehidrasi, kadar serat pangan, kalsium dan kontribusi zat gizinya.

\section{Waktu rehidrasi}

Waktu rehidrasi bubur bayi instan dengan formulasi tepung garut dan tepung kacang merah terbaik (70:30) dapat dilihat pada Tabel 6.

Tabel 6. Waktu rehidrasi (detik) bubur bayi instan dengan formulasi tepung garut dan tepung kacang merah 70:30

\begin{tabular}{ccc}
\hline Ulangan & $\begin{array}{c}\text { Formulasi Tepung Garut dan } \\
\text { Tepung Kacang Merah 70:30 } \\
\text { (detik) }\end{array}$ & $\begin{array}{c}\text { Bubur Bayi Instan Komersial } \\
\text { (detik) }\end{array}$ \\
\hline 1 & 39,5 & 48,7 \\
\hline 2 & 40,3 & 49,4 \\
\hline Rata-rata & 39,6 & 49,4 \\
\hline
\end{tabular}

Tabel 6 menunjukkan bahwa bubur bayi instan dengan formulasi tepung garut dan tepung kacang merah terbaik yaitu formulasi 70:30, waktu optimal rehidrasi atau waktu larutnya adalah selama 39,8 detik. Waktu rehidrasi tersebut lebih rendah dari waktu rehidrasi bubur bayi komersial yaitu sebesar 49,1 detik, sehingga diduga bubur bayi instan formulasi 70:30 memiliki daya rehidrasi atau daya larut yang lebih baik dibanding bubur bayi instan komersial.

\section{Serat pangan dan kalsium}

Hasil uji serat pangan dan kalsium dapat dilihat pada Tabel 7.

Tabel 7. Hasil uji serat pangan dan kalsium

\begin{tabular}{ccc}
\hline Zat Gizi & $\begin{array}{c}\text { Bubur bayi instan formulasi tepung garut dan } \\
\text { tepung kacang merah 70:30 }\end{array}$ & $\begin{array}{c}\text { Syarat mutu MP-ASI bubuk instan } \\
\text { (SNI 01-7111.4-2005) }\end{array}$ \\
\hline Serat pangan & $9,64 \%$ & $<5 \mathrm{~g} / 100 \mathrm{~g}$ \\
\hline Kalsium & $360,49 \mathrm{mg} / 100 \mathrm{~g}$ & $>200 \mathrm{mg} / 100 \mathrm{~g}$ \\
\hline
\end{tabular}

Serat pangan total bubur bayi instan formulasi 70:30 adalah sebesar 9,64\% melebihi standar yang ditetapkan oleh SNI (< $5 \mathrm{~g} / 100 \mathrm{~g}$ bahan). Dengan demikian, bubur bayi instan formulasi tepung garut dan tepung kacang merah 70:30 tidak memenuhi kadar serat yang ditetapkan. Hasil analisis kadar kalsium menunjukkan bahwa bubur bayi instan terpilih mengandung kalsium sebesar 360,49 $\mathrm{mg} / 100 \mathrm{~g}$ yang berarti bahwa bubur bayi instan memenuhi standar SNI dimana kalsium dalam MP-ASI bubuk instan disyaratkan berkisar antara $200-400$ $\mathrm{mg} / 100 \mathrm{~g}$.

\section{Kontribusi zat gizi bubur bayi instan}

Sumbangan kecukupan gizi per takaran saji bubur bayi instan formulasi tepung garut dan tepung kacang merah terbaik terhadap Angka Kecukupan Gizi (AKG) dan Acuan Label Gizi (ALG) dapat dilihat pada Tabel 8.

Tabel 8. Sumbangan kecukupan gizi per takaran saji bubur bayi instan

\begin{tabular}{lcccccc}
\hline Zat Gizi & $\begin{array}{c}\text { Kandungan } \\
\text { Zat Gizi/100 g }\end{array}$ & $\begin{array}{c}\text { Kandungan } \\
\text { per Takaran } \\
\text { Saji } \\
\mathbf{( 5 0 ~ g ) ~}\end{array}$ & $\begin{array}{c}\text { AKG 2013 } \\
\text { (Bayi 7-11 } \\
\text { bulan) }\end{array}$ & \% AKG & $\begin{array}{c}\text { ALG 2007 } \\
\text { (Bayi 7-23 } \\
\text { bulan) }\end{array}$ & \% ALG \\
\hline Energi (Kkal) & 392 & 196 & 725 & 27,03 & - & - \\
\hline Protein (g) & 16,38 & 8,19 & 18 & 45,5 & 20 & 40,95 \\
\hline Kalsium (mg) & 360,49 & 180,24 & 250 & 72,1 & 480 & 37,55 \\
\hline
\end{tabular}


Tabel 8 menunjukkan bahwa konsumsi satu takaran saji bubur bayi instan formulasi tepung garut dan tepung kacang merah $70: 30$ dapat memenuhi $27,03 \%$ kecukupan energi, 45,5\% kecukupan protein dan $72,1 \%$ kecukupam mineral kalsium yang dianjurkan untuk bayi usia 7-11 bulan per hari. Bubur instan terbaik memberi kontribusi protein sebesar 40,95\% ALG anak usia 7-23 bulan sehingga dapat diklaim sebagai pangan tinggi protein. Menurut BPOM (2011), pangan yang dapat memenuhi lebih dari $35 \%$ protein ALG untuk kategori usia tertentu dikategorikan sebagai pangan tinggi protein. Sementara itu, BPOM (2011) menyatakan syarat klaim untuk pangan dengan kandungan mineral tertentu adalah lebih dari $15 \%$ sebagai sumber mineral dan lebih dari $30 \%$ sebagai pangan tinggi mineral. Dengan demikian, formula bubur bayi instan terpilih formulasi 70:30 dapat diklaim sebagai pangan tinggi kalsium $(37,55 \%)$.

\section{KESIMPULAN}

Ada perbedaan terhadap mutu kimia (kadar air, abu, protein, lemak, dan karbohidrat), mutu fisik (viskositas, daya serap air, dan densitas kamba), mutu organoleptik (kekentalan pada bubur bayi yang sudah diseduh, lalu warna, aroma, dan tekstur pada bubur bayi instan yang tidak diseduh) pada bubur bayi instan yang dibuat dari formulasi tepung garut dan tepung kacang merah yang berbeda. Bubur bayi instan fomulasi tepung garut dan tepung kacang merah terbaik adalah formulasi 70:30, formulasi tersebut memiliki karakteristik kadar air $6,47 \%$, abu $3,71 \%$, protein $16,38 \%$, lemak $6,62 \%$, karbohidrat $66,82 \%$, serat pangan $9,64 \%$, kalsium 360,49 mg/100 g, viskositas $556,67 \mathrm{cp}$, daya serap air 161,49\%, densitas kamba $0,560 \mathrm{~g} / \mathrm{ml}$, waktu rehidrasi 39,8 detik, warna coklat muda $(4,07)$, aroma tidak langu $(3,95)$, rasa agak manis $(3,11)$, tekstur lembut $(3,69)$, dan kekentalan agak kental $(3,09)$. Karakteristik bubur bayi instan terbaik sesuai dengan SNI 01-7111.1-2005 pada kalori, lemak, protein dan kalsium. Densitas kamba dan waktu rehidrasi bubur bayi instan lebih baik nilainya dari bubur bayi instan komersial. Karakteristik yang masih belum sesuai adalah karbohidrat, kadar air, kadar abu dan kadar serat yang masih lebih tinggi dari SNI, Penelitian lebih lanjut perlu dilakukan dengan memperbaiki proses pembuatan bubur bayi instan guna menurunkan karbohidrat, kadar air, kadar abu dan kadar serat agar diperoleh nilai yang dapat memenuhi standar SNI, dengan formulasi dengan menggunakan bahan lokal lain atau bahan tambahan pangan lain agar dapat menghasilkan bubur bayi instan dengan nilai gizi yang sesuai dengan standar SNI.

\section{DAFTAR PUSTAKA}

Badan Pengawas Obat dan Makanan [BPOM]. 2011. Keputusan Kepala Badan Pengawas Obat dan Makanan tentang Pengawasan Klaim dalam Label dan Iklan Produk Pangan Olahan. BPOM, Jakarta.

Badan Pusat Statistik (BPS). 2013. Tabel Produksi Sayuran di Indonesia 19972013. http://www.bps.go.id/. Diakses tanggal 3 Desember 2014.

Cahyani, K.D. 2011. Kajian Kacang Merah (Phaseolus vulgaris) sebagai Bahan Pengikat dan Pengisi pada Sosik Ikan Lele. Tugas Akhir. Universitas Sebelas Maret, Surakarta.

Chilmijati, N. 1999. Karakteristik Pati Garut dan Pemanfaatannya sebagai Sumber Bahan Baku Glukosa Cair (Tesis). Progam Pasca Sarjana. Bogor : Institut Pertanian Bogor.

Dirjen Tanaman Pangan. 2013. Pedoman Teknis Pengelolaan Produksi Ubi Jalar dan Aneka Umbi 2013. Kementerian Pertanian. Jakarta.

Elvizahro, L. 2011. Kontribusi MP-ASI Bubur Bayi Instan dengan Sustitusi Tepung lkan Patin dan Tepung Labu Kuning terhadap Kecukupan Protein dan Vitamin A pada Bayi. Artikel Penelitian. Program Studi IImu Gizi. Fakultas Kedokteran. Universitas Diponegoro, Semarang. 
Fernando, E.R. 2008. Formulasi Bubur Susu Kacang Tanah Instan Sebagai Alternatif Makanan Pendamping ASI. Tugas Akhir. Bogor: IPB.

Pontoh, J., Nurally E., and Rondonuwu P.. 2004. Extrusion of Cassava and Several Palm Technology. J. American Association of Cereal Chemists. St. Paul Minnesota.

Kartikasari, O. 2006. The Application of Red Bean Flour in Red Bean Instant Soup: It's Physical, Chemical, and Sensory Evaluation. UKS. Semarang.

Koswara, S. 2013. Teknologi Pengolahan Umbi-umbian: Pengolahan Umbi Garut. Bogor: IPB.

Krisnatuti, D. dan Yenrina R. 2000. Menyiapkan Makanan Pendamping ASI. Puspa Swara. Jakarta.

Mirdhayati, I. 2004. Formulasi dan Karakteristik Sifat-sifat Fungsional Bubur Garut Instan Sebagai Makanan Pendamping Air SUsu Ibu (MP-ASI). Tesis Sekolah Pasacasarjana. Institut Pertanian Bogor. Bogor.

Muhilal, F.J. dan Hardiansyah. 2013. Angka Kecukupan Gizi yang Dianjurkan. Widakarya Nasional Pangan dan Gizi.

Mulya, S. 1994. Pembuatan Makanan Sapihan (Weaning Food) dari Campuran Perkatan Protein Ikan Bandeng dan Tepung Beras. Skripsi Sarjana Program Studi Pengolahan Hasil perikanan, Fakultas Perikanan, IPB. Bogor.

Rukmana, H.R. 2009. Buncis. Penerbit Kanisius. Yogyakarta.

Standar Nasional Indonesia (SNI). 2005. Makanan Pendamping Air Susu Ibu Bagian 1 : Bubuk Instan. Badan Standarisasi Nasional. Jakarta. (SNI 01-7111.4-2005).
Widowati, S., Nurjana R. dan Amrinola W. 2010. Proses Pembuatan dan Karakterisasi Nasi Sorgum Instan. Prosiding Pekan Serealia Nasional. IPB. Bogor.

Wirakartakusumah, M.A., Abdullah K. dan Syarief A.M.. 1992. Sifat Fisik Pangan. PAU Pangan Gizi IPB. Bogor. 